\title{
Study of Elaeidobius spp. and Grasidius hybridus population activity using a new trapping method during oil palm anthesis (Coleoptera, Curculionidae)
}

\author{
by Laurence Beaudoin-Ollivier ${ }^{1}$, Albert Flori ${ }^{2}$, Indra Syahputra ${ }^{3}$, \\ Leifi NodichaO ${ }^{4}$, Roberto Poveda ${ }^{5} \&$ Claude Louise $^{6}$ \\ ${ }^{1}$ Cirad, UPR Bioagresseurs, avenue du Campus Agropolis, F - 34398 Montpellier, France <laurence.ollivier@cirad.fr>
${ }^{2}$ Cirad, UPR Systèmes de pérennes, avenue du Campus Agropolis, F - 34398 Montpellier, France <albert.flori@cirad.fr>
${ }^{3}$ PT Socfindo SSPL, Bangun Bandar, 20991 Sumatera Utara, Indonésie <indras@socfindo.co.id>
${ }^{4}$ Inrab, Centre de recherche agricole palmier à huile, BP 01, Pobè, Bénin < anleifi@yahoo.com>
${ }^{5}$ Palmeras del Ecuador s. a., Avenida Eugenio Espejo, 2410 y Rincón del Valle, Quito, Équateur <rpoveda@danec.com>
${ }^{6}$ Palmelit SAS, Parc agropolis, 2214 boulevard de la Lironde, F - 34980 Montferrier-sur-Lez, France
<claude.louise@palmelit.com>
}

(Accepté le 03.III.2017)

Abstract. - A new design of interception trap has been developed to study the activity of two major oil palm pollinator insects, the weevils Elaeidobius spp. and Grasidius hybridus, visiting inflorescences in anthesis. The trap has been studied for the two species Elaeis guineensis (West Africa, South-east Asia and South America) and Elaeis oleifera and two interspecific hybrids (South America). The results allowed the identification of the period of insect activity during anthesis and the monitoring of the species and number of insects visiting both male and female inflorescences in anthesis. The trap design seems convenient for future population dynamics and dispersal studies in oil palm plantations. The results indicate that Elaeidobius spp. have diurnal flying activity whereas such activity occurs during dusk to nocturnal periods for $G$. hybridus. The weevils are highly host-specific, but variability is apparent for hybrids.

Résumé. - Étude de l'activité des populations d'Elaeidobius spp. et Grasidius hybridus à l'aide d'une nouvelle méthode de piégeage pendant l'anthèse du Palmier à huile (Coleoptera, Curculionidae). Un nouveau modèle de piège à interception a été conçu pour étudier l'activité des principaux insectes pollinisateurs du palmier à huile, les charançons Elaeidobius spp. et Grasidius hybridus, au voisinage des inflorescences en anthèse. Le piège a été testé pour les deux espèces de palmier à huile, Elaeis guineensis en Afrique de l'Ouest, Asie du Sud-Est et Amérique du Sud, et Elaeis oleifera et deux hybrides interspécifiques en Amérique du Sud. Les résultats permettent d'identifier les périodes d'activité des insectes pendant l'anthèse et d'identifier les espèces et les effectifs des insectes visitant les inflorescences mâles et femelles en anthèse. Le modèle de piège apparaît performant pour les études de dynamique des populations et de dispersion dans les plantations de palmier à huile. Les résultats indiquent qu'Elaeidobius spp. a une activité de vol diurne alors que G. hybridus a une activité en début de nuit ou au cours de la nuit. Les charançons sont très spécifiques de leur plante-hôte mais il existe une variabilité au sein des hybrides.

Keywords. - Pollination, oil palm, inflorescence, interception trap, Benin, Indonesia, Ecuador.

Oil palms, Elaeis spp. (Arecales, Arecaceae), are cultivated for the oil extracted from the mesocarp of their fruits and from their seeds. They are monoecious with unisexual inflorescences on the same palm in successive cycles that require cross-pollination and the help of an external agent in pollination to ensure a good fruit set. The oil palm was considered to be anemophilous for a long time (Turner \& Gillbanks, 1974; Hardon \& Corley, 1976; Hartley, 1977; Purseglove, 1985) until Syed $(1979,1981)$ found that the pollen is mainly transported by small local weevils in Africa (Coleoptera, Curculionidae, Derelomini) and that such weevils enhanced pollination to a large extent in South America (GENTY et al., 1986).

The African oil palm is visited by more than one insect group in its area of origin in West Africa where pollination is adequate. The genus Elaeidobius Kuschel, 1952 (Coleoptera, Curculionidae) predominates on Elaeis guineensis Jacquin, the most widespread oil palm 
species, and in the area where Elaeidobius was artificially introduced in 1981 due to poor natural pollination to improve pollination and fruit set, assisted pollination is no longer needed (SYed, 1982; Basri et al., 1985; Chiu et al., 1986; Ponnamma et al., 2006; Appiah \& Agyei-Dwarko, 2013). In Latin America, the native Mystrops costaricensis Gillogly, 1972 (Coleoptera, Nitidulidae) and the likely introduced Elaeidobius subvittatus (Faust, 1898) (Coleoptera, Curculionidae) have been observed in Costa Rica and in the Manaus region in Brazil respectively on Elaeis oleifera (Kunth) Cortès inflorescences (Wood, 1983), oil palm originated from South and Central America. Where these two insect species are present, they are also found on E. guineensis inflorescences but they are not effective enough to pollinate this palm. Elaeidobius kamerunicus (Faust, 1898), has then been introduced to improve pollination to ensure a reasonable percentage of fruit set in particular areas where $E$. guineensis is cultivated (Wood, 1983; Syed, 1984; Corrado, 1985; Genty et al., 1986; Mariau \& Genty, 1988). Individuals of Grasidius hybridus O'Brien \& Beserra, 2004, Couturierius carinifrons O'Brien \& Beserra, 2004, C. constrictirostris O’Brien \& Beserra, 2004 (Coleoptera, Curculionidae, Derelomini) native to South America (Amazonian area), have been discovered on E. oleifera (Taisha, Ecuador). G. hybridus has been introduced and has been maintained on hybrid crosses of the two oil palm species, which are grown as the only alternative to E. guineensis in areas facing bud rot disease (O'BRIEN et al., 2004).

The increasing femininity of the highest producing E. guineensis cultivars and the low natural pollination of interspecific hybrids $(E$. guineensis $\times$ E. oleifera) cause fruit set to be a limiting factor in some areas, and questions have arisen to improve it. The pollination of Elaeis spp. and its impact on fruit set have been studied by numerous researchers in Africa (Syed, 1979; Lecoustre \& Reffye, 1987; Mariau et al., 1991; Hala et al., 2012; Appiah \& Agyei-Dwarko, 2013), Asia (Williams \& Hsu, 1979; Tay, 1981; Syed, 1981, 1982, 1994; Wood, 1985; Chiu et al., 1986; Syed \& Saleh, 1988; Dhileepan, 1992; Jyoti \& Saradamani, 1994; Dhileepan, 1994; Cik Mohd Rizuan et al., 2013; Yue et al., 2015) and the South Pacific (CAudwell et al., 2003; LAWTON, 1982), and there have also been contributions on pollination from South and Central America (WoOd, 1983; Genty et al., 1986; Mariau \& GenTy, 1988; Chinchilla \& Richardson, 1991; Beserra, 2003; Labarca et al., 2007; LabarCa \& Narváez, 2009). The pollination of oil palm is dependent on pollen availability and subsequently the number and activity of pollinating insects carrying and transferring pollen to receptive female inflorescences, particularly at a young age. The activity of pollinator insects has a direct effect on the fruit set rate and, consequently, on the production of well-formed fruits in a bunch. An increase in yield is a consequence of an increasing number of bunches per tree, which has an impact on pollinator populations, as the male inflorescences allow adults to feed and mate and facilitate the breeding of their own pollinators. A lower ratio of male flowers in improved genotypes or a lower attractivity of the interspecific hybrid $E$. guineensis $\times$ E. oleifera to pollinating insects may be responsible for a pronounced under-pollination phenomenon (SYED, 1982; Lecoustre \& ReFFye, 1987). The population of E. kamerunicus has been found to fluctuate considerably depending on the region (SYed, 1984; BASRi et al., 1985; Prior \& MENENDEZ, 1985; LuBIS \& SIPAYUNG, 1986). The natural pollination process is thought to be controlled by scent emitted by inflorescences, promoted by heat production, which attract Elaeidobius (SILBERBAUERGottsberger, 1990; Opute, 1975; Lajis et al., 1985; Hussein et al., 1989). The male inflorescence, in which the insects develop, is highly attractive to Elaeidobius and, through an olfactory deception phenomenon, they visit the female inflorescence, on which they deposit pollen, only during anthesis. There is therefore a mutual exchange between the insect and the plant. According to observations carried out in Cameroon, we know that the insects are mainly active in the vicinity of male inflorescences during the first five days and in the vicinity of female inflorescences during the first day of anthesis (RIPOLL, 2009). 
Various techniques have been tested in the field as monitoring procedures for sampling the species to facilitate qualitative and quantitative identification and to study the fluctuation in the pollinators attracted by both male and female inflorescences during anthesis of the two species and their interspecific hybrids: samples of spikelets have been collected during the first hours during the first four days of anthesis to estimate the adult population level (SYED, 1979, 1981; Syed \& SaleH, 1988; Chinchilla \& Richardson, 1991; Yue et al., 2015); the number of weevils visiting female inflorescences in anthesis was counted using traps coated with colourless and odourless sticky materials (Pest-o-lure traps) (DHILEEPAN, 1994); a trap made with white plastic tape $5 \mathrm{~cm}$ in width and impregnated with a mouse glue solution diluted in free unleaded gasoline was placed around a female inflorescence in anthesis to evaluate the proportions of insect species (LABARCA \& NARVÁEZ, 2009); trapping methods used by CHIU et al. (1986) appeared to be too variable to monitor the weevil population in the field; a white cloth covering/enclosing the inflorescence or a glued transparent tape $(3 \times 30 \mathrm{~cm})$ was used for capturing the pollinators (Chinchilla \& Richardson, 1991; KirejtShuK \& Couturier, 2010; TAY, 1981); and sweep nets have been used to collect insects within the proximity of male and receptive female inflorescences, which were then bagged. Sticky traps encircling inflorescences have been considered to be an optimal technique to obtain reliable data (YUE et al., 2015). However, hiding the inflorescence may affect insect attraction. Overall, none of these methods provided a reliable estimate, and for female inflorescences, several methods were unsuccessful (SYED \& SALEH, 1988).

Some recent studies in Indonesia, Benin and Ecuador designed to gain a clearer understanding of pollination in the oil palm led us to propose a new trap design for both species of cultivated oil palms, E. guineensis and E. oleifera, and their interspecific hybrids.

The purpose of the trap described in this article is to serve as a simple, suitable and reliable technique to focus on the activities of the main pollinating insects visiting flowers during anthesis, to monitor their population fluctuations over the year, to determine their relationships with flowers during anthesis and to get an idea of the level of pollinator insects required for adequate pollination.

\section{Materials AND Methods}

Observations of pollinator insect activity were conducted in three oil palm plantations in March and December 2010 and January 2012. The plantations were located at Socfindo in Indonesia (E. guineensis La Mé origin, 10-year-old oil palms), at Institut National de la Recherche Agronomique (INRAB) Pobè in Bénin (E. guineensis La Mé origin, 5-year-old oil palms, and E. oleifera Brazil Mangenot, 32 years old) and in Ecuador at Shushufindi, PDE (11-year-old E. guineensis, 10-year-old E. oleifera and two interspecific hybrids, SA-2203 and SA-1511, which were 13-15-year-old oil palms).

To identify and quantify species, we designed interception traps. The interception traps were composed of transparent Plexiglas plates $(190 \times 100 \times 2 \mathrm{~mm})$, which were drilled at each corner $8 \mathrm{~mm}$ from the border (diam. $4 \mathrm{~mm}$ ) and hung $10 \mathrm{~cm}$ above an inflorescence by links tied to the petioles of the palm. A transparent sheet $(150 \times 70 \mathrm{~mm})$ (HP Premium Inkjet Transparency Film $^{\circledR}$, Hewlett-Packard Company, Italy) covered with horticultural glue (Rampastop gel ${ }^{\circledR}$, Protecta Sas, Le Thor, France) was placed on both sides of the plate using two pieces of invisible tape $(40 \times 19 \mathrm{~mm})\left(\right.$ Scotch Magic $3 \mathrm{M}^{\circledR}$, Cergy-Pontoise, France) on which the reference information for the trap was noted (sex of the inflorescence and number) (fig. 1). The insects were trapped and glued by interception during their flight around and in the vicinity of the inflorescences. The traps were set up in the field above male and female inflorescences during anthesis at the period of the day of the highest activity of Elaeidobius sp. (MARIAU et al., 1991; RIPOLL, 2009). Insects were intercepted either leaving or visiting an inflorescence. After the period of trapping, the glued transparent sheets were removed from the Plexiglas plate and 


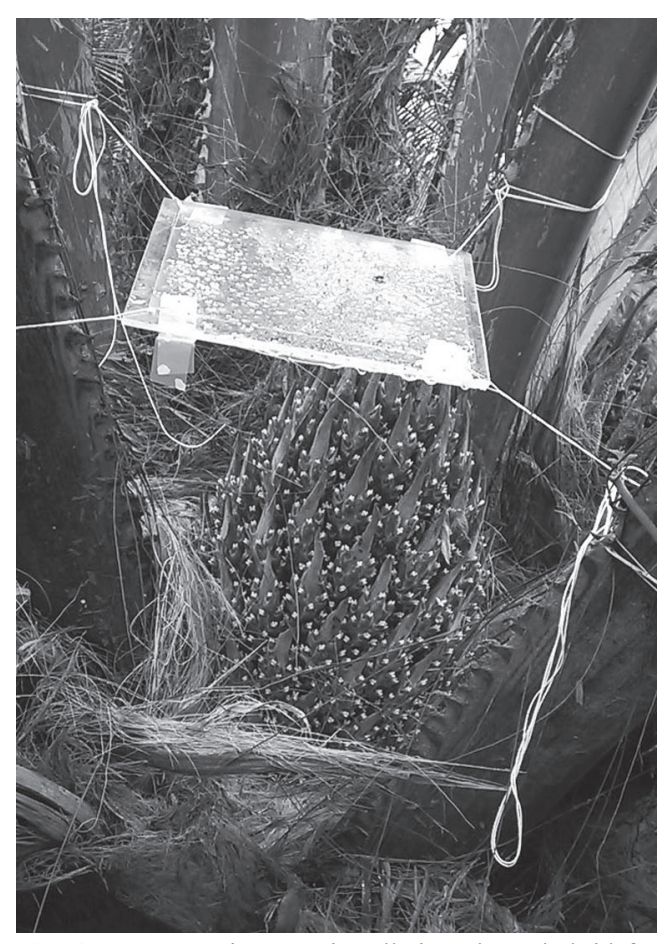

Fig. 1. - Interception trap installation above hybrid female inflorescence of Elaeis in anthesis. (Photo: Thomas Auffray). then protected with transparent foil on which the sticky tape with the reference information was transferred. The insects captured on each side of the above plates placed in the vicinity of inflorescences were identified and counted. The species identifications and capture scores were determined with a portable $20 \times$ magnification stereoscopic microscope (Naturescope, Nikon, Japan). The identification of Elaeidobius spp. occurred using a simple identification key (RIPOLl, 2009). Grasidius hybridus was also identified (O'BriEn et al., 2004). The numbers of insects captured on both sides of the trap were combined.

In Indonesia, two traps per inflorescence on the third and fourth day of anthesis were installed above one male and three female inflorescences of E. guineensis from 9.00 a.m. to 11.30 a.m. Two traps per inflorescence in anthesis were set up in Benin from 9.00 a.m. to 11.30 a.m. above two male and two female inflorescences of both E. guineensis and E. oleifera on the first day of anthesis. For E. oleifera, the two traps were installed from 9.00 a.m. above one male and one female inflorescence in anthesis to $9.00 \mathrm{a} . \mathrm{m}$. on the second day of anthesis, but identification and quantification of the trapped insects were conducted at $11.30 \mathrm{a} . \mathrm{m}$. on the first day of anthesis. In Ecuador, one trap per inflorescence was installed from 9.00 a.m. on the first day of anthesis and then remained in place beyond 5.30 p.m. until the next day at 9.00 a.m. Four female and two male inflorescences on hybrids (SA-2203 in block D5B) and three female and three male inflorescences on hybrid SA-1511 in block E4A were observed. One male and one female inflorescence on both E. oleifera Taisha (block D5C) and E. guineensis Tenera (block C7B) were observed.

For the Indonesia data, sex ratio differences in E. kamerunicus were tested using Poisson regression. For the Benin data, the average numbers of Elaeidobius for the inflorescences of both sexes of E. guineensis were compared using a Poisson regression. The computations were conducted by applying generalized linear mixed models (PROC GLIMMIX, SAS Institute) (SAS InstituTe, 2011).

\section{Results}

The captures on the traps represent the movement of the weevils around the inflorescences. The trapping technique revealed that the trap is resistant to inclemency (wind and rainfall) and that a part of it is disposable whereas the other is sustainable.

In Indonesia, the records for the traps for the one male (Male Flower in Anthesis MFA1) and three female (Female Flower in Anthesis FFA1, FFA2, and FFA3) E. guineensis inflorescences in anthesis revealed variability in the activity of the insects per inflorescence. The only insects identified were the weevils Elaeidobius kamerunicus for both male and female inflorescences. 
The number of insects visiting the female inflorescences during anthesis varied from 4 to 106 per inflorescence, and there was no significant difference in the sex ratio of the insects trapped $(\mathrm{F}=0.57$ and $\mathrm{P}=0.5)$. The number of insects visiting the MFA1 was 21 male and 32 female E. kamerunicus (fig. 2). No Thrips hawaiiensis (Morgan, 1913), a low pollinating capacity pollinator insect of oil palm in Southeast Asia, were found on the sticky traps during the period of anthesis of the observed inflorescences.

The interception traps around male and female E. oleifera inflorescences in anthesis in Benin did not capture any insects from $9.00 \mathrm{a} . \mathrm{m}$. to $11.30 \mathrm{a} . \mathrm{m}$. on the first and the second day of anthesis. A single Elaeidobius subvittatus individual was glued to one trap set up at the top of a male inflorescence.

However, many insects were captured on the interception traps installed at the top of E. guineensis male and female inflorescences on the first day of anthesis. These insects belonged mainly to the genus Elaeidobius and were identified as E. kamerunicus (males and females), E. subvittatus, E. plagiatus (Fåhraeus, 1844) (males and females), Atheta burgeoni Bernhauer, 1930 (Staphylinidae) as well as other small unidentified Coleoptera. The average number of trapped E. subvittatus (males and females together) was higher (44, standard error (SE): 3.3) than that of the two other Elaeidobius species (9 (SE: 1.6) for E. kamerunicus and 16 (SE: 2) for E. plagiatus). Additionally, there was no difference between female and male flowers in anthesis for any of the Elaeidobius species ( $\mathrm{F}=3$ and $\mathrm{P}>0.1)$ (fig. 3).

In Ecuador, the interception traps did not catch any insects in the daytime $(9.00 \mathrm{a} . \mathrm{m}$. to 5.30 p.m.) within the vicinity of male or female flowers of E. oleifera Taisha in anthesis (FFA5, MFA3) (fig. 4a). For the SA-2203 hybrids during the same period, only E. kamerunicus was recorded on the interception traps for both male and female inflorescences in anthesis (FFA1, FFA3, MFA1 and MFA2). We noted that the number of E. kamerunicus trapped within the vicinity of one male inflorescence was significantly higher (206 on MFA2) than that for another male inflorescence ( 5 for MFA1). The four female inflorescences in anthesis attracted few or no insects ( 23 on FFA1 and 0,1 and 0 on FFA2, FFA3 and FFA4, respectively) (fig. 4a). At dusk or during the night (5.30 p.m. to 9.00 a.m.), pollinator insects were only trapped on male and female E. oleifera Taisha inflorescences (FFA5 and MFA3), whereas no more captures were observed on the SA-2203 hybrids during this period of trapping (fig. 4b). The identification of the insects from the sticky traps revealed only one species, the weevil Grasidius hybridus on both male (175 on MFA3) and female inflorescences (27 on FFA5) of E. oleifera Taisha in anthesis (fig. 4b).

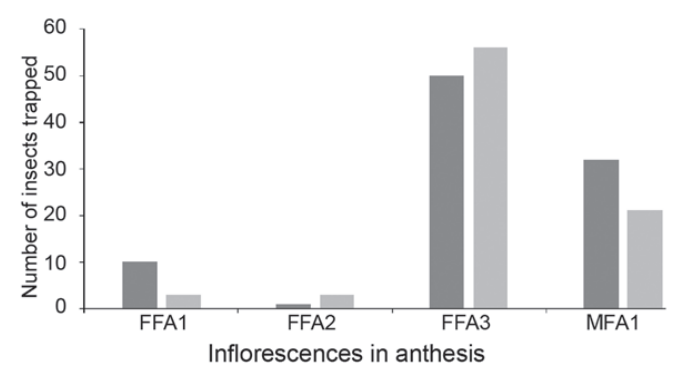

(FFA: female flower in anthesis; MFA: male flower in anthesis 2 $\square$ E. kamerunicus 우

$\square$ E. kamerunicus ${ }^{\pi}$

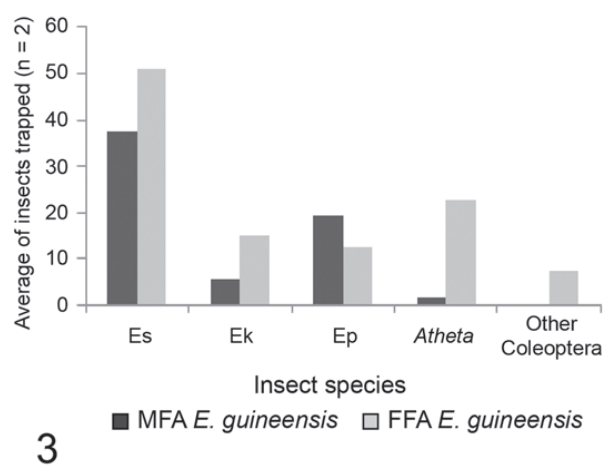

3

Fig. 2-3. - 2, Activity of Elaeidobius kamerunicus (Faust) visiting one male and three female inflorescences of Elaeis guineensis in anthesis in Indonesia. - 3, Average number of insects trapped around Elaeis guineensis male and female inflorescences in anthesis in Benin (Es: Elaeidobius subvittatus (Faust), Ek: E. kamerunicus (Faust), Ep: E. plagiatus (Fåhraeus). 
The interception sticky traps installed for $24 \mathrm{hrs}$ within the vicinity of SA-1511 hybrids, E. guineensis, E. oleifera Taisha and the hybrid SA-2203 (9.00 a.m. to 9.00 a.m. the next day) revealed high variability in the number of insects trapped. Within the vicinity of the SA-1511 hybrids, specimens of $G$. hybridus were predominantly recorded ( 88 on MFA4 to 127 adults on FFA8), whereas this species was not recorded on the SA-2203 hybrids in the daytime. Indeed, only E. kamerunicus were present on the traps within the vicinity of both male and female inflorescences on E. guineensis (27 individuals per inflorescence for FFA9 and MFA7). No G. hybridus were seen on these interception traps. As seen for the SA-2203 hybrids, the insects remained more abundant in the vicinity of male inflorescences than female inflorescences in anthesis for the SA-1511 hybrids and E. oleifera (fig. 5). However, we noted one trap placed in the vicinity of the female inflorescences (FFA8) captured a large number of G. hybridus (127 individuals).

\section{Discussion}

This trapping method has revealed its ability to capture pollinating insects visiting oil palm inflorescences. The advantages of this interception sticky trap lie in the fact it used a colourless and odourless glue that does not disrupt the natural attraction or behaviour of the pollinators towards the inflorescences. The trap is also not affected by meteorological disturbances such as wind or rain that are observed in the field, and the use of the sticky brush allows the disadvantages of manual stickiness to be avoided. The advantages of this shape of interception trap include continuous trapping day and night, suitability for both male and female inflorescences and both oil palm species, and inexpensiveness (costing less than \$ 1 USD each) because they are handmade with material locally available and once in place, they require little attention. The transparent foils with glued insects may be stored for later analysis. Finally, most of the hard parts of the trap are sustainable.

The disadvantage may be that the transparent foil makes weevil sex identification difficult, particularly when many Elaeidobius individuals are found on the same trap, as in the weevil area of origin in the Gulf of Guinea. Also, the position of the trap above the inflorescence probably affects the flow of attractive odours due to temperature elevation of the anthesis inflorescence. The direct effect is that the traps may capture more insects coming out than coming in of the inflorescence.

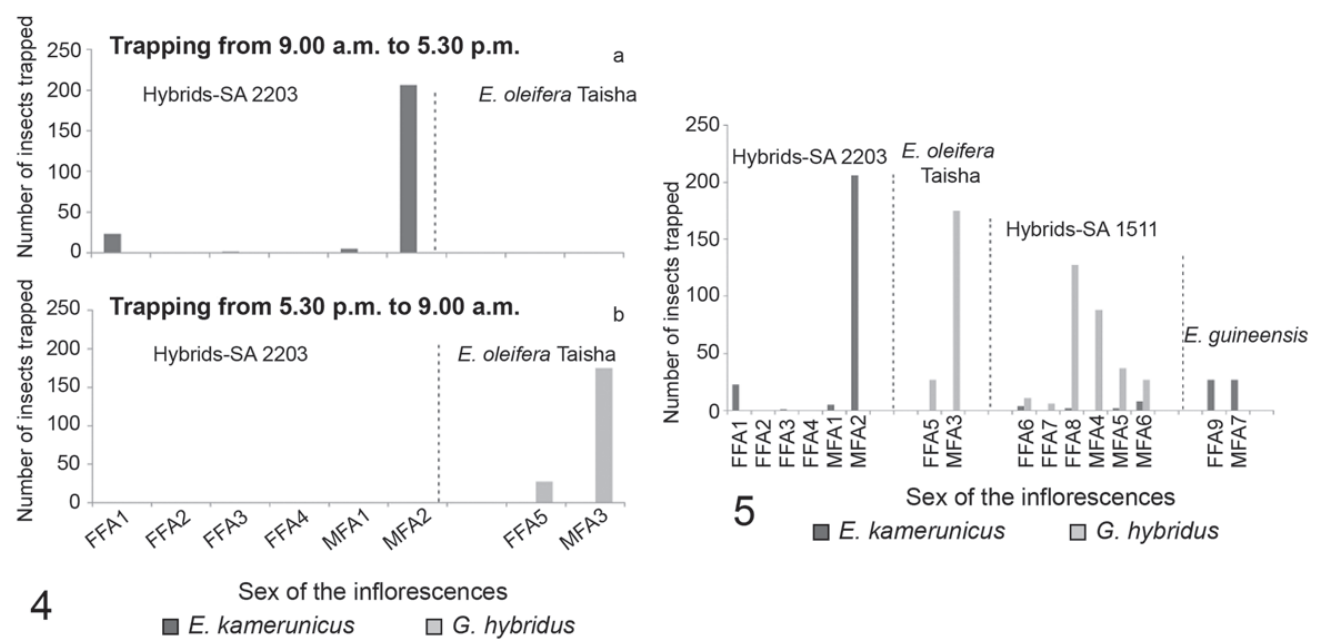

Fig. 4-5. - 4, Number of insects trapped on hybrid SA-2203 and Elaeis oleifera from (a) 9.00 a.m. to 5.30 p.m. and then from (b) 5.30 p.m. to 9.00 a.m. the following day in Ecuador. - 5, Number of insects trapped on hybrid SA-2203, Elaeis oleifera Taisha, hybrid SA-1511 and E. guineensis over 24 hrs (9.00 a.m. to 9.00 a.m. the following day) in Ecuador. (FFA, Female flower in anthesis; MFA, Male flower in anthesis). 
Unfortunately, the possibilities of large-scale use in the field appear limited. Indeed, although the method is rapid (less than $3 \mathrm{~min}$ ), the need to move the traps at the end of anthesis makes them rather onerous and requires the transfer of the traps.

The results obtained from the interception traps are in accordance with those found in the literature.

The interception traps described in this study confirmed the existence of the weevil genus Elaeidobius in Benin associated with both male and female E. guineensis inflorescences in anthesis during the highest period of activity of the insects during the daytime. The three main pollinator species, E. kamerunicus, E. subvittatus and E. plagiatus, are naturally found on the African oil palm E. guineensis in its area of origin as described by Syed (1979) and DeSMIER DE CHENon (1981). E. oleifera trapped only E. subvittatus during the daytime. This species has been identified on both E. guineensis and E. oleifera. This shows E. subvittatus is not restricted to the West African oil palm (SYED, 1982). It can maintain a breeding population on both (HowARD et al., 2001). The insects visiting oil palms in Cameroon seem to be very specialized for some E. oleifera palms examined, and except for a large number of E. subvittatus, there were fewer abundant species on E. guineensis, and none of these species were found on date palms or palms of several other species that are planted along roadsides (SYED, 1979). The interception traps confirmed that only E. kamerunicus is active within the vicinity of both male and female E. guineensis inflorescences in anthesis during the daytime in Indonesia, where the weevil was successfully introduced and established (SYED, 1982). The results of catches of Curculionidae using the interception traps confirmed the attractivity of the inflorescences. The weevils are attracted to the staminate flowers by a strong anise-like scent promoted by the warming of the inflorescences (GENTY et al., 1986). The insects identified by the interception traps for E. guineensis, E. oleifera and their hybrids were not members of Hymenoptera or Diptera. Syed (1979) also found only very few such specimens on receptive female inflorescences in Cameroon. Thermogenesis seems to only occur in species without nectaries and is most likely associated with cantharophily. Cantharophilous palms rarely have nectaries. Therefore, the female inflorescences are rarely visited by Hymenoptera or Diptera (SiLBERBAUER-GotTSBERGER, 1990). While no insects were seen on the interception traps in the vicinity of two E. oleifera Taisha inflorescences (male and female) during the daytime in Ecuador, the night-time trapping revealed that a pollinator species of the genus Grasidius, native to South America (O'BRIEN et al., 2004), was active at night, particularly in the vicinity of the male rather than the female inflorescence of the hybrids in not insubstantial numbers. This result suggests that Grasidius hybridus visiting E. oleifera Taisha inflorescences in anthesis are not active during the day but are present when the male inflorescence in anthesis has been threshed. E. oleifera may be characterized by nocturnal anthesis and thermogenesis (SILBERBAUER-GotTSBERGER, 1990). No Grasidius insects were seen on the traps on E. guineensis. Indeed, only E. kamerunicus were present on the traps. It cannot be said that those E. kamerunicus were trapped during the night given that the traps were inspected early in the morning at approximately 9.00 a.m., and it is not impossible that these captures were due to the flight of the insects on the same morning. However, the insects remained few in number and did not exceed 6 individuals. This was the same case for the hybrids.

We found that the flight activity of E. kamerunicus insects was only observed around one of the two male hybrid inflorescences observed. The 4 female inflorescences in anthesis attracted few or no insects. Only one side of a trap in the vicinity of a female inflorescence captured approximately twenty insects. E. kamerunicus and G. hybridus were both found to be active on hybrids. In contrast to G. hybridus, which is active at dusk, E. kamerunicus arrived during the daytime. The species of African weevils are less attracted to hybrid crosses (O'BRIEN et al., 2004). 
The nitidulid Mystrops costaricensis pacificus Gillogly, 1972, a native species, was not present on the interception traps in the observation area in Ecuador. M. costaricensis is exclusively found on oil palm in Mexico, Honduras, Costa Rica, Ecuador, Colombia and Paraguay (MARIAU \& Genty, 1988; KirejtschuK \& Couturier, 2010). Elaeidobius subvittatus was not found.

The species collected by these interception traps are likely the most common active species present on the oil palm species sampled in Benin, Indonesia and Ecuador (MARIAU \& GENTY, 1988). Cantharophily involving Curculionidae is considered to be the most important category of entomophily in palms (HENDERSON, 1986). E. kamerunicus is restricted to E. guineensis, and $G$. hybridus exclusively visits the inflorescences of E. oleifera or their interspecific hybrids, E. guineensis $\times$ E. oleifera. Members of the Elaeidobius genus exclusively visit flowers of the palm genus Elaeis (MARIAU et al., 1991). Tests have shown that E. kamerunicus could not exist for long on the flowers of other palms (HENDERSON, 1986). The pollinator insects of oil palm are specialists, also known as monolectics because they visit a single botanical species. Genera of these large families appear to be specific to palm flowers, and the degree of specificity may be very marked (Syed, 1979, 1982; ADAIGBE et al., 2011). The interception trap data confirm the specialized nature of the subfamily Derelominae of the family Curculionidae (LEPESME, 1947; Syed, 1979, 1981).

At this stage, despite the low number of inflorescences studied, the results indicate that the new interception trap can be used profitably in conjunction with visual observations to gain information about temporal distribution, host specificity and attractivity. Although interception traps provide a measure of relative abundance, they primarily provide a measure of flight activity within the vicinity of the inflorescences in anthesis. The development and the use of these new interception sticky traps allowed the G. hybridus activity period to be identified, which was previously unknown. With its standardized use, the trap allows the accumulation of catches over the five days of anthesis, and its effectiveness does not decrease. However, it cannot be said that the insects caught on the interception sticky traps were insects attracted by the inflorescences. All that can be confirmed is that these insects were active in the vicinity of the inflorescences without being able to say whether the insects were immigrants (inflorescence attraction) or emigrants (insects leaving the inflorescence).

\section{Conclusion}

It is undeniable that without the use of pheromones or attractive compounds, the interception sticky trap is a useful tool for recording pollinators visiting inflorescences and for carrying out population dynamics or dispersal studies using capture-mark-recapture techniques. The standardization of the trap would be convenient for comparing the results gathered by several scientists to improve the knowledge regarding oil palm pollination. The visual direct counting may evolve towards automatization by digitization and shape recognition.

Acknowledgements. - This work was financially supported by Palmelit SAS Cooperation, and field logistical support was provided by INRAB-Crapp Pobé in Benin, Socfindo at Bangun Bandar in Indonesia and Palmas del Ecuador, Danec in Ecuador. We would like to thank Dr L. Nodichao and Mr A. Coffi in Benin, Mr H. Williams in Indonesia, and Mr S. Gutt and Mr I. Noboa in Ecuador for their support and approval for conducting these experiments. Thanks also to $\mathrm{Mr} \mathrm{T}$. Auffray for helpful comments regarding the manuscript.

\section{Auteurs Cités}

Adaigbe V. C., Odebiyt J. A., Omoloye A. A., Aisagbonhi C. I. \& Lyare O., 2011. - Host location and ovipositional preference of Elaeidobius kamerunicus on four host palm species. Journal of Horticulture and Forestry, 3 (5) : 163-166.

ApPiah S. O. \& AgYei-Dwarko D., 2013. - Studies on entomophil pollination towards sustainable production and increased profitability in the oil palm: a review. Elixir Agriculture, 55 : 12878-12883. 
Basri W. M., Tan Y. P., Liau S. S., Hassan A. H., Hussein M. Y., Dolmat M. T., Ismail S., Tan C. C., Quah Y. T., Ho C. T. \& WAN I. A., 1985. - The population census and the pollination efficiency of the weevil Elaeidobius kamerunicus Faust, in Peninsular Malaysia, 1983, a preliminary report. Palm Oil Research Institute of Malaysia, $8: 9-33$.

BESERRA P., 2003. - Informe de avance del programa de introducción de insectos polinizadores nativos en PDE. Mérida-Venezuela, Octubre de 2003, 13 p.

Caudwell R. W., Hunt D., Reid A. \& Mensah B. A., 2003. - Insect Pollination of oil palm - An evaluation of the long-term viability and sustainability of Elaeidobius kamerunicus. The Planter, 79 : 75-91.

Chinchilla C. M. \& Richardson D. L., 1991. - Pollinating insects and the pollination of oil palms in Central America. ASD Technical Bulletin, 2 : 1-18.

Chiu S. B., Kноо K. C. \& Hussern M. Y., 1986. - A method of estimating the natural population of the pollinating weevil, Elaeidobius kamerunicus Faust, of oil palm. In : Hussein M. Y. \& Ibrahim A. G. (eds), Biological control in the tropics: proceedings of the "First Regional Symposium on Biological Control”. Universiti Pertanian Malaysia Serdang from 4-6 September 1985 : 453-470.

Cik Mohd Rizuan Z. A., Noor Hisham H. \& Samsudin A., 2013. - Role of pollinating weevil (Elaeidobius kamerunicus), seasonal effect and its relation to fruit set in oil palm area of FELDA. Pipoc 2013 Conference, KLCC, Kuala Lumpur, Malaysia, November 19-21 : 1-4.

Corrado F., 1985. - La conformation des régimes de palmier à huile (Elaeis guineensis Jacq.) dans quelques plantations de Colombie. Oléagineux, 40 : 173-187.

Desmier de Chenon R., 1981. - Entomophil pollination of oil palm in West Africa, Preliminary Research (p. 291-319). In: The oil palm in the eighties. A report of the Proceedings of the International Conference on Oil Palm in Agriculture in the Eighties. Kuala Lumpur from 17-20 June 1981. Volume I.

DHILEEPAN K., 1992. - Pollen carrying capacity, pollen load and pollen transferring ability of the oil palm pollinating weevil Elaeidobius kamerunicus Faust in India. Oléagineux, 47 : 56-61.

- 1994. - Variation in populations of the introduced pollinating weevil (Elaeidobius kamerunicus) (Coleoptera: Curculionidae) and its impact on fruit set of oil palm (Elaeis guineensis) in India. Bulletin of Entomological Research, $84:$ 477-485.

Genty P., Garzon A., Lucchini F. \& Delvare G., 1986. - Polinización entomófila de la palma Africana en America tropical. Oléagineux, $41: 99-112$.

Hala N., Tuo Y., Akpesse A. A. M., Koua H. K. \& Tano Y., 2012. - Entomofauna of oil palm tree inflorescences at La Mé expérimental station (Côte d'Ivoire). American Journal of Experimental Agriculture, 2 : 306-319.

Hardon J. J. \& Corley R. H. V., 1976. - Pollination (p. 299-305). In : Corley R. H. V., Hardon J. J. \& Wood B. J. (eds), Oil palm Research. Amsterdam : Elsevier Scientific Publishing, 532 p.

Hartley C. W. S., 1977. - The oil palm. $3^{r d}$ ed. Tropical Agriculture Series. London : Longman, 761 p.

Henderson A., 1986. - A review of pollination studies in the Palmae. The Botanical Review, 52 : 221-259.

Howard F. W., Moore D., Giblin-Davis R. M. \& Abad R. G., 2001. - Insects on palms. Wallingford : CABI Publishing, $400 \mathrm{p}$.

Hussein M. Y., Lajis N. H., Kinson A. \& Teo C. B., 1989. - Laboratory and field evaluation on the attractancy of Elaeidobius kamerunicus Faust to 4-allylanisole. Porim Bulletin, 18 : 20-26.

Jyoti P. V. \& Saradamani N., 1994. - Pollinating agents of oil palm. A study on plantations in Andhra Pradesh. Indian Oil Palm Journal, 4 : 24-26.

KirejtshuK A. \& Couturier G., 2010. - Sap beetles of the tribe Mystropini (Coleoptera: Nitidulidae) associated with South American palm inflorescences. Annales de la Société entomologique de France, (N. S.) $46: 367-421$.

LABARCA M. V. \& NARVÁEZ Z., 2009. - Identificación y fluctuación poblacional de insectos polinizadores en palma aceitera (Elaeis guineensis Jacquin) en el sur del lago de Maracaibo, estado Zulia, Venezuela. Revista de la Facultad de Agronomía, 26 (3) : 305-324.

Labarca M. V., Portillo E. \& Narváez Z., 2007. - Relación entre las inflorescencias, el clima y los polinizadores en el cultivo de la palma aceitera (Elaeis guineensis Jacquin) en el sur del lago de Maracaibo. Revista de la Facultad de Agronomía, 24 (2) : 303-320.

Lajis N. H., Hussein M. Y. \& Toia R. F., 1985. - Extraction and identification of the main compound present in Elaeis guineensis flower volatiles. Pertanika, 8 : 105-108. 
Lawton D. M., 1982. - Pollination and fruit set in oil palm (Elaeis guineensis Jacq.) [in Papua New Guinea]. In : Pushparajah E. \& Chew P. S. (eds), The Oil Palm in Agriculture in the Eighties. Kuala Lumpur.

Lecoustre R. \& Reffye P. DE, 1987. - Méthode d'estimation de la part due à la pollinisation dans l'expression du taux de nouaison. Oléagineux, 42 (5) : 175-183.

LePeSme P., 1947. - Les insectes des Palmiers. Paris : Paul Lechevalier, 903 p.

LuBIS A. U. \& SiPAYUNG A., 1986. - Evaluation on the 3-Year occurrence of oil palm pollinating weevil, Elaeidobius kamerunicus in Indonesia. Temu Ilmiah Entomologi Perkebunan Indonesia : 1-18.

Mariau D. \&. Genty P., 1988. - Contribution de l'IRHO à l'étude des insectes pollinisateurs du palmier à huile en Afrique, en Amérique du Sud et Indonésie. Oléagineux, 43 : 233-240.

Mariau D., Houssou M., Lecoustre R. \& Ndigui B., 1991. - Insectes pollinisateurs du palmier à huile et taux de nouaison en Afrique de l'ouest. Oléagineux, $46: 43-51$.

O'Brien C. W., Beserra P. \& Couturier G., 2004. - Taxonomy of Couturierius, new genus and Grasidius, genus new to South America, palm flower weevils in the Derelomini (Coleoptera, Curculionidae), Revue française d'Entomologie, (N. S.) 26 : 145-156.

Opute F. I., 1975. - Identification of p.Methoxyallybenzene in the pollen of the oil palm Elaeis guineensis Jacq. Journal of Experimental Botany, 26 : 619-623.

Ponnamma K. N., SajeebKhan A. \& Vijayan A., 2006. - Adverse factors affecting the population of pollinating weevil, Elaeidobius kamerunicus F. on fruit set on oil palm in India. The Planter, 82 : 555-557.

Purseglove J. W., 1985. - Tropical Crops: Monocotyledons, $5^{\text {th }}$ impression, revised and updated. New York : Longman, $607 \mathrm{p}$.

Prior R. N. B. \& MENEndeZ T., 1985. - Investigations 603, Elaeidobius kamerunicus field studies. Annual Report PNGOPRA : 43-48.

Ripoll J., 2009. - Interaction entre les inflorescences du palmier à huile Elaeis guineensis J. et leurs pollinisateurs du genre Elaeidobius spp. (Coleoptera: Curculionidae) en Afrique. Mémoire de stage de master 1 BGAE, Université Montpellier 2, 35 p.

SAS Institute, 2011. - SAS/STAT 9.3. User's guide. SAS Institute, Cary, NC.

Silberbauer-Gottsberger I., 1990. - Pollination and evolution in palms, Phyton, 30 : 13-233.

SYED R. A., 1979. - Studies on oil palm pollination by insects. Bulletin of Entomological Research, 69 : 213-224. 1981. - Insect pollination of oil palm: Feasibility of introducing Elaeidobius spp. into Malaysia (p. 263-289). In : Pushparajah E. \& Chew P. S. (eds), The Oil Palm in Agriculture in the Eighties. Kuala Lumpur.

_ 1982. - Insect pollination of oil palm: Introduction, establishment and pollinating efficiency of Elaeidobius kamerunicus in Malaysia. The Planter, 58 : 547-561.

— 1984. - Los insectos polinizadores de la palma africana. Palmas, 5 : 19-87.

1994. - Insect pollination of oil palm - A proven success, new vistas of producing high yielding oil palm. International Oil Palm Journal, 4 : 12-21.

Syed R. A. \& Saleh A., 1988. - Population of Elaeidobius kamerunicus Fst. in relation to fruit set (p. 528-534). In : Halim Hassan A. et al. (eds), Proceedings 1987 Internatioanl Oil Palm Conference 'Progress and Prospects'. Oil Research Institute Malaysia, Kuala Lumpur.

TAY K. C., 1981. - Observations on insects visiting oil palm inflorescences, The Planter, 57 : 82-91.

Turner P. D. \& GIllbanks R. A., 1974. - Oil palm cultivation and management. Kuala Lumpur : Incorporated Society of Planters, $672 \mathrm{p}$.

Williams C. N. \& Hsu Y. C., 1979. - Fruit Production and pollination (p. 114-121). In : Oil palm cultivation in Malaysia. University of Malaya Press.

Wood B. J., 1983. - Note on insect pollination of oil palm in South and Central America. The Planter, $59: 167-170$.

— 1985. - Some consequences of weevil pollination of the oil palm in South East Asia (p. 423-438). The oil palm Symposium, Pusat Penelitian Marihat, Medan, March 27-28.

Yue J., Yan Z., Bai C., Chen Z., Lin W. \& JiAo F., 2015. - Pollination activity of Elaeidobius kamerunicus (Coleoptera: Curculionidea) on oil palm on Hainan island. Florida Entomologist, 98 : 499-505. 